\title{
Influence Different Methods of Mechanical Activation on Yield Extractive Substances from Pine Bark
}

\author{
Evgenia V. Veprikova ${ }^{a *}$, Vladislav A. Ionin ${ }^{a}$, \\ Mikhail Yu. Belash ${ }^{\mathrm{a}}$, Andrei M. Skripnikov ${ }^{\mathrm{a}, \mathrm{b}}$, \\ Aleksandr V. Levdanskiii and Oxana P. Taran ${ }^{\mathrm{a}, \mathrm{b}}$ \\ ${ }^{a}$ Institute of Chemistry and Chemical Technology SB RAS \\ FRC "Krasnoyarsk Science Center SB RAS" \\ Krasnoyarsk, Russian Federation \\ ${ }^{b}$ Siberian Federal University \\ Krasnoyarsk, Russian Federation
}

Received 20.04.2020, received in revised form 12.06.2020, accepted 12.09.2020

\begin{abstract}
The effect pine bark activation by explosive autohydrolysis and mechanical treatment in a ball mill on the yield and properties of resinous and pectin substances and $\beta$-sitosterol was studied. Pine bark physicochemical properties after its activation by a batch of methods were studied. It was shown that the activation of pine bark by explosive autohydrolysis result in the highest increase in the yield of extractive substances. The conditions providing the highest yield of target products from the activated pine bark were determined: for resinous substances and $\beta$-sitosterol - the use of $0.5 \mathrm{n}$ alkali solution; for pectin substances - the use of hydrochloric acid.
\end{abstract}

Keywords: pine bark, explosive autohydrolysis, ball mill, resinous substances, $\beta$-sitosterol, pectine substances.

Citation: Veprikova E.V., Ionin V.A., Belash M.Yu., Skripnikov A.M., Levdanskii A.V., Taran O.P. Influence different methods of mechanical activation on yield extractive substances from pine bark, J. Sib. Fed. Univ. Chem., 2020, 13(3), 430-446. DOI: 10.17516/1998-2836-0196

(C) Siberian Federal University. All rights reserved

This work is licensed under a Creative Commons Attribution-NonCommercial 4.0 International License (CC BY-NC 4.0).

* Corresponding author E-mail address: veprikova2@mail.ru 


\title{
Влияние различных способов \\ механической активации на выход \\ экстрактивных веществ из коры сосны
}

\author{
Е.В. Веприкова ${ }^{\text {a }, ~ В . А . ~ И о н и н ~}{ }^{a}$ М.Ю. Белаш ${ }^{a}$, \\ А.М. Скрипников ${ }^{\mathrm{a}, \boldsymbol{\sigma}}$, А.В. Левданский ${ }^{\mathrm{a}}$, О.П. Таран ${ }^{\mathrm{a}, \boldsymbol{\sigma}}$ \\ ${ }^{a}$ Институт химии и химической технологии СО РАН \\ ФИЦ «Красноярский научный изентр СО РАН» \\ Российская Федерация, Красноярск \\ ${ }^{6}$ Сибирский федеральньий университет \\ Российская Федерация, Красноярск
}

Аннотация. Исследовано влияние активации коры сосны взрывным автогидролизом и механической обработкой в барабанной мельнице на выход и свойства смолистых и пектиновых веществ и $\beta$-ситостерин. Изучены физико-химические свойства коры сосны после ее активации различными способами. Показано, что активация коры сосны взрывным автогидролизом приводит к наибольшему увеличению выхода экстрактивных веществ. Определены условия, обеспечивающие наибольший выход целевых продуктов из активированной коры сосны: для смолистых веществ и $\beta$-ситостерина - применение 0.5 н раствора щелочи; для пектиновых веществ - использование соляной кислоты.

Ключевые слова: кора сосны, взрывной автогидролиз, барабанная мельница, смолистые вещества, $\beta$-ситостерин, пектиновые вещества.

Цитирование: Веприкова, Е.В. Влияние различных способов механической активации на выход экстрактивных веществ из коры сосны / Е.В. Веприкова, В.А. Ионин, М.Ю. Белаш, А.М. Скрипников, А.В. Левданский, О.П. Таран // Журн. Сиб. федер. ун-та. Химия, 2020. 13(3). С. 430-446. DOI: 10.17516/1998-2836-0196

\section{Введение}

Регионы Сибири, в частности Красноярский край, являются лидерами в лесной отрасли России. Красноярский край лидирует по объему лесных угодий в России, составляющих 14,5 \%, или 158,7 млн га, в том числе 114,9 млн га эксплуатационных и защитных лесов $[1,2]$. Большую площадь в Красноярском крае занимают хвойные леса. Общий запас древесины составляет 11,5 млрд кубометров, в том числе 9,5 млрд кубометров по хвойным насаждениям [2]. Наиболее ценна в хозяйственном отношении сосна, которая по объему лесозаготовок находится на первом месте и составляет около 70 \% заготавливаемого древесного сырья $[1,3]$. Так, в 2017 г. объем лесозаготовок был равен 23,1 млн кубометров, в 2018 г. - около 25 млн кубометров, это максимальный объем по России.

Проблема утилизации кородревесных отходов в России относится к числу наиболее актуальных, так как при существующих методах переработки в настоящее время теряется почти половина биомассы дерева, что говорит о низком уровне технологических процессов де- 
ревообработки. Из примерно 60 млн м³ ежегодно образующихся отходов почти три четверти приходится на долю лесопиления. Анализ показателей баланса использования сырья на предприятиях Красноярского края показывает, что при низком объемном выходе пиломатериалов (45-47 \%) и, соответственно, при больших объемах отходов (47-49 \%) последние используются нерационально [3]. В результате на предприятиях ЛПК накопилось огромное количество кородревесных отходов.

Все это обусловливает высокую актуальность для Красноярского края создания новых методов безотходной переработки коры сосны, которая по своему составу является более ценным химическим сырьем, чем древесина, благодаря наличию востребованных экстрактивных веществ.

Цель настоящей работы - разработка новых методов экстракционного фракционирования сосновой коры на ценные экстрактивные вещества (смолистые и пектиновые вещества, $\beta$-ситостерин) с использованием экологически безопасных растворителей и активирующих воздействий взрывного автогидролиза и механоактивации в барабанной мельнице.

\section{Экспериментальная часть}

\section{Подготовка и активация коры соснь}

В качестве исходного материала использовали измельченную воздушно-сухую кору сосны. Измельчение осуществляли на роторной ножевой мельнице марки РМ-120 с диаметром сита 3 мм. Далее производили фракционирование на виброгрохоте марки ГР-30 и выделяли фракцию коры размером $1-3$ мм.

Механохимическую активацию коры сосны проводили обработкой в барабанной мельнице и методом взрывного автогидролиза (ВАГ).

Активация на лабораторной барабанной мельнице типа МЛ-1 (Группа предприятий “Промстроймаш”, г. Калуга) проходила при комнатной температуре следующим образом: навеску коры сосны массой 50 г засыпали в фарфоровый барабан объемом 10 л с наружным диаметром 280 мм; затем в барабан загружали фарфоровые шары со смещенным центром тяжести в количестве 24 штук общей массой 1500 г; плотно закрывали барабан фарфоровой крышкой с прокладкой и помещали на обрезиненные вальцы мельницы. Барабанная мельница снабжена частотным преобразователем для плавной регулировки частоты вращения электродвигателя привода вальцов, что позволяет точно установить требуемую частоту вращения барабана. Частоту вращения устанавливали на максимум - 72 об·мин ${ }^{-1}$. Продолжительность активации составляла 1 ч.

Активирующая обработка коры сосны методом ВАГ проходила в реакторе объемом 0,8 л на установке периодического действия, описанной в работе [4], при следующих условиях: температура процесса $120^{\circ} \mathrm{C}$; время выдержки $30 \mathrm{c}$; давление водяного пара 1 МПа (для поддержания давления на заданном уровне при необходимости в реактор подавали дополнительное количество водяного пара). Сырье массой 50 г загружали в реактор (шаровой кран для сброса давления закрыт), предварительно нагретый на 60-70 \% от выбранной температуры процесса. Затем закрывали реактор крышкой и подавали водяной пар из парогенератора. Давление контролировали с помощью манометра. После определенного времени выдержки давление резко сбрасывали до атмосферного путем открытия шарового крана реактора, расположенного в нижней его части. При этом автогидролизованный материал “выстреливался” из реактора в

$$
-432-
$$


специальный приемник. Автогидролизованный материал сушили до воздушно-сухого состояния при комнатной температуре.

\section{Экстракиионная обработка образиов коры сосны}

В качестве исходного сырья для выделения экстрактивных веществ использовали три образца: 1) измельченную (фракция размером 1-3 мм) воздушно-сухую кору сосны (ИСХ); 2) образец коры после механической обработки в барабанной мельнице в течение 1 ч (MXA); 3) образец, активированный методом взрывного автогидролиза при давлении 1 МПа (ВАГ).

Для выделения $\beta$-ситостерина навеску образца коры массой до 13 г экстрагировали гексаном в аппарате Сокслета при 65-70 ${ }^{\circ} \mathrm{C}$ в течение 4-16 ч. Растворитель отгоняли на роторном испарителе. Смолистые вещества, оставшиеся после отгонки гексана, растворяли в 100 мл 0,5-1 н спиртового раствора $\mathrm{NaOH}$ при нагревании на водяной бане до $65-70{ }^{\circ} \mathrm{C}$ в течение 1 ч в круглодонной колбе. Полученные растворы разбавляли водой в 4 раза, $\beta$-ситостерин трижды экстрагировали диэтиловым эфиром в делительной воронке. Эфирную фракцию объединяли и сушили над сульфатом натрия. Эфир отгоняли на роторном испарителе.

Для получения пектинов твердый остаток после удаления из образцов коры сосны смолистых веществ обрабатывали этиловым спиртом при $80{ }^{\circ} \mathrm{C}$ в аппарате Сокслета. Остаток коры промывали водой и сушили. Далее высушенный остаток коры делили пополам, одну часть обрабатывали 50-100 мл 1\%-го раствора соляной, вторую - 50-100 мл 1\%-го раствора ортофосфорной кислоты в течение 1 часа при температуре $80{ }^{\circ} \mathrm{C}$ в круглодонной колбе. Полученные растворы фильтровали на воронке Бюхнера. Твердый остаток сушили на воздухе, затем исследовали физико-химическими методами. К полученным растворам добавляли около 50 мл изопропилового спирта до осаждения пектинов. Пектины собирали фильтрованием на воронке Бюхнера. Осадок дважды промывали небольшим количеством изопропилового спирта, сушили на воздухе до постоянного веса.

\section{Физико-химические исследования исходной и активированной коры}

Электронно-микроскопические исследования проводили на электронных растровых микроскопах ТМ-1000 и ТМ-3000 (HITACHI, Япония). Регистрация ИК-спектров выполнена на ИК-Фурье-спектрометре IR Tracer-100 (Shimadzu, Япония) в области 4000 - 400 см$^{-1}$. Образцы готовили в виде таблеток в матрице бромистого калия при одинаковых условиях (2 мг на 1000 мг бромида калия). Полученная спектральная информация была обработана с помощью пакета программ LabSolutions IR.

Рентгенофазовый анализ образцов коры проводили на дифрактометре ДРОН-3 с использованием $\mathrm{CuK \alpha -монохроматизированного} \mathrm{излучения} \mathrm{(} \lambda=0,154$ нм), напряжение 30 кВ, ток 25 мА. Шаг сканирования 0,02 град; интервалы по 1 с на точку данных. Измерение проводили в интервале углов Брэгга $2 \Theta$ от 5,00 до 70,00 град. Индекс кристалличности (ИК) целлюлозы, входящей в состав коры сосны, рассчитывали приближенным способом по формуле

$$
\text { ИК }=\left(\mathrm{I}_{002}-\mathrm{I}_{\mathrm{AM}}\right) / \mathrm{I}_{002} \text {, }
$$

где $\mathrm{I}_{002}$ - интенсивность пика при $2 \Theta=22,3-22,5$; $\mathrm{I}_{\mathrm{AM}}$ - интенсивность в точке перегиба при $2 \Theta=17,9-18,5^{\circ}$. 
Физико-химический анализ экстрактивных вещуеств

Строение $\beta$-ситостерина и пектиновых веществ определяли методом ИК-спектроскопии

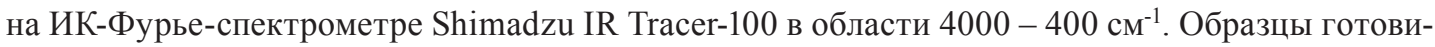
ли в виде таблеток в матрице бромистого калия при одинаковых условиях для каждой партии (2,5 и 3 мг на 1000 мг бромида калия для смолистых веществ и пектиновых веществ соответственно). Полученная спектральная информация была обработана с помощью пакета программ LabSolutions IR.

Запись спектров ЯМР проводили на спектрометре Avance III 600 (Bruker, Германия) Красноярского центра коллективного пользования ФИЦ КНЦ СО РАН. Все спектры записывали при $24.5^{\circ} \mathrm{C}$ в 5 мм ампулах. Спектры ${ }^{1} \mathrm{H}$ растворов $\beta$-ситостеринов в хлороформе-Д были получены путем накопления восьми последовательных сканирований с релаксационной задержкой 5 сек. Спектры HSQC были записаны с применением методики редактированного корреляционного эксперимента из библиотеки стандартных импульсных последовательностей (hsqced, Bruker). Корреляционные спектры получены накоплением 32 последовательных сканирований и 128 экспериментам. Спектры ${ }^{1} \mathrm{H}$ растворов пектинов в тяжелой воде записывали с применением методики насыщения сигнала растворителя селективным импульсом в течение 8 сек. Химические сдвиги даны в миллионных долях. В качестве внутреннего стандарта использовали пики остаточных протонов растворителей (7.28 м.Д. - хлороформ-Д, 4.75 м.Д. - $\mathrm{D}_{2} \mathrm{O}$ ).

\section{Результаты и обсуждение}

\section{Влияние разных способов активащии}

на физико-химические свойства коры сосны

Известно, что результатом взрывного автогидролиза (ВАГ) древесного сырья являются механическая деструкция обрабатываемых частиц и термохимические превращения органической массы под действием повышенной температуры и давления в среде водяного пара [5]. Механохимическая активация в мельницах разного типа приводит не только к измельчению частиц обрабатываемого лигноцеллюлозного материала, но и к разрушению структуры полимеров в его составе (аморфного лигнина, целлюлозы и др). В результате этого повышается реакционная способность коры [6-9].

Поскольку в литературе отсутствуют данные о воздействии взрывного автогидролиза и механоактивации в барабанной мельнице на структуру пектиновых веществ и $\beta$-ситостерина, авторы работы выбрали условия проведения этих процессов с целью достижения разрушения частиц коры сосны при наименее возможном химическом преобразовании ее органических составляющих.

O разрушении частиц коры сосны в результате выбранных способов активации свидетельствует появление в составе получаемых продуктов фракции менее 1,0 мм - в среднем 40 мас. \%.

Представленные на рис. 1 изображения показывают, что активация коры сосны методом ВАГ приводит к изменениям ее текстуры. В результате такого воздействия на поверхности коры сосны появляются крупные поры размером от 20,5 до 60,7 мкм по сравнению с исходной корой. Также на поверхности активированного образца наблюдается наличие единичных мелких пор размером 7,5 - 12,8 мкм (рис. 1a, б). У образца после активации коры в барабанной мельнице не идентифицировано изменений ее пористой структуры (рис. $1 a, 8)$.

$$
-434-
$$



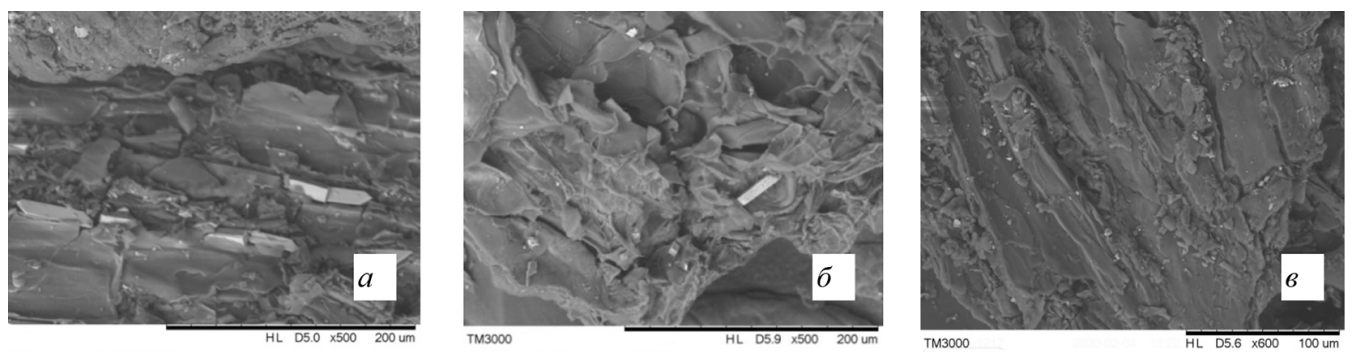

Рис. 1. Микрофотографии исходной коры сосны (a), образцов после ее активации взрывным автогидролизом (б) и в барабанной мельнице (в). Условия взрывного автогидролиза: температура $120{ }^{\circ} \mathrm{C}$, время 30 с; давление водяного пара 1,0 МПа. Продолжительность активации в барабанной мельнице 1 ч. Увеличение $(a, \sigma)-500$ раз, (в) - 600 раз

Fig. 1. Microimages of initial pine bark $(a)$, samples after her activation by explosive auto hydrolysis $(\sigma)$ and in ball mill (B). The conditions of explosive auto hydrolysis: temperature $120{ }^{\circ} \mathrm{C}$, time $30 \mathrm{~s}$, water vapour pressure 1,0 MPa. Time of activation in ball mill $1 \mathrm{~h}$. Magnification $(a, \sigma)-500$ times, $(b)-600$ times

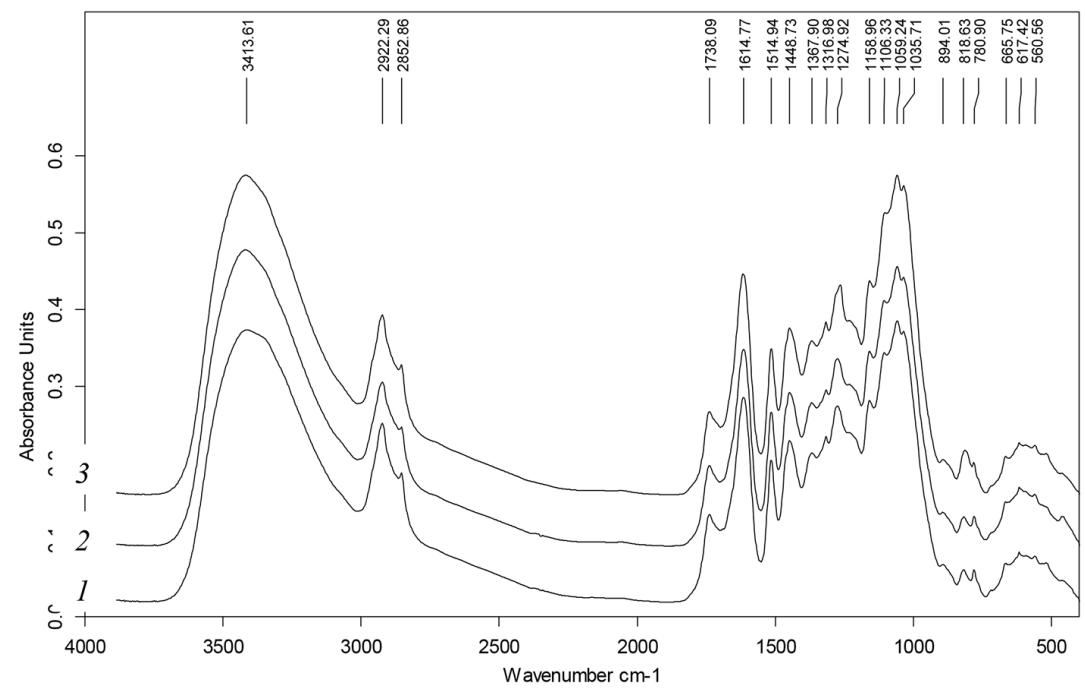

Рис. 2. ИК-спектры исходной коры сосны (1), образцов после ее активации в барабанной мельнице (2) и после взрывного автогидролиза (3). Условия взрывного автогидролиза: температура $120{ }^{\circ} \mathrm{C}$, время $30 \mathrm{c}$; давление водяного пара 1,0 МПа. Продолжительность активации в барабанной мельнице 1 ч

Fig. 2. IR-spectrum of initial pine bark (1), samples after her activation in ball mill (2) and after explosive auto hydrolysis (3). The conditions of explosive auto hydrolysis: temperature $120{ }^{\circ} \mathrm{C}$, time $30 \mathrm{~s}$, water vapour pressure 1,0 MPa. Time of activation in ball mill $1 \mathrm{~h}$

На рис. 2 приведены ИК-спектры исходной коры и образцов после ее активации ВАГ и в барабанной мельнице. Сопоставление полученных результатов показывает, что активация коры сосны разными способами не смещает характеристические полосы поглощения (п.п.), но влияет на изменение их интенсивности (рис. 2, кривые $1-3$ ).

После активации коры сосны в барабанной мельнице в течение 1 ч в ИК-спектре зафиксировано заметное увеличение интенсивности только п.п. с максимумом при $3414 \mathrm{~cm}^{-1}$ (валентные колебания ОН-групп различного характера). Интенсивность поглощения в области 
1160 - $1000 \mathrm{~cm}^{-1}$ сопоставима с поглощением в данной области для исходной коры. Отмечено незначительное уменьшение интенсивности п.п. при 2922 и 2853 см$^{-1}$ (колебания алифатических $-\mathrm{CH}_{3}$ и $-\mathrm{CH}_{2}$-групп), 1738 см$^{-1}$ (колебания $\mathrm{C}=\mathrm{O}$-групп разной природы), 1614 и $1514 \mathrm{~cm}^{-1}$ (колебания ароматического кольца, связи $\mathrm{C}-\mathrm{O}$ в карбоксилат-ионе, связи $\mathrm{C}=\mathrm{C}$ в алкенах и др. $[10,11])$ по сравнению с корой до активации (рис. 2, кривые 1,2 ).

В ИК-спектре образца после активации коры сосны взрывным автогидролизом отмечено увеличение интенсивности п.п. с максимумом при $3414 \mathrm{~cm}^{-1}$ по сравнению с исходной корой и образцом, полученным активацией в барабанной мельнице. Данная п.п. обусловлена валентными колебаниями ОН-групп различного характера. Эти группы входят, в частности, в состав фенольных соединений, первичных, вторичных и третичных спиртов $[10,11]$. О повышении содержания спиртов свидетельствует увеличение интенсивности п.п. в области $1000-1160 \mathrm{~cm}^{-1}$ в сравнении с другими образцами (рис. 2, кривые $1-3$ ). Наблюдаемое увеличение интенсивности отмеченных п.п. может быть обусловлено термохимическими превращениями кетонов, альдегидов, карбоновых кислот и их функциональных производных, входящих в состав коры сосны. Наличие в реакционной среде водяного пара, очевидно, способствует образованию спиртов разной природы [5]. Поглощение в указанной области также может быть вызвано колебаниями С-О-С-связей в циклических и алифатических простых эфирах [10, 11]. Увеличение интенсивности п.п. при 1514 см$^{-1}$ (валентные С-Ссвязи) в ИК-спектре продукта после ВАГ указывает на увеличение количества неконденсированных ароматических соединений в его составе. Увеличение интенсивности п.П. при $1614 \mathrm{~cm}^{-1}$ может быть обусловлено образованием, в частности, карбоксилат-ионов $[10,11]$ (рис. 2, кривые 1, 3).

Сравнение спектральных картин образцов коры сосны, активированных разными способами, показывает, что взрывной автогидролиз приводит к более существенному изменению химико-группового состава коры (рис. 2, кривые 2 и 3 ).

\section{Влияние различных способов активации}

\section{на кристалличность целлюлозы коры сосны}

Активацию целлюлозы и содержащей целлюлозу биомассы проводят не только для измельчения сырья, но и с целью перевести химически инертную кристаллическую целлюлозу в более реакционноспособное аморфное состояние $[9,12,15,16]$. Изменение индекса кристалличности при активации коры сосны, определяемое из полученных методом рентгенофазового анализа дифрактограмм, характеризует степень разрушения кристаллической целлюлозы и позволяет оценить эффективность выбранных способов активирующей обработки.

Активация коры сосны методом ВАГ и в барабанной мельнице приводит к увеличению ИК. Очевидно, при выбранных условиях активирующих обработок происходит разрушение только аморфной составляющей целлюлозы. Причем наибольшая ее деструкция достигается в процессе измельчения в барабанной мельнице, что подтверждает сравнение значений ИК (табл. 1).

Дифрактограммы, по которым были определены соответствующие значения ИК, приведены на рис. 3.

$$
-436-
$$


Таблица 1. Индекс кристалличности (ИК) коры сосны до и после активации

Table 1. The crystallinity index (IC) of pine bark before and after activation

\begin{tabular}{|l|l|l|}
\hline Образец & Условия активации & ИК \\
\hline ИСХ & Без активации & 0,35 \\
\hline ВАГ & Взрывной автогидролиз, температура $120{ }^{\circ} \mathrm{C}$, время 30 с, давление 1,0 МПа & 0,37 \\
\hline МХА & Барабанная мельница, продолжительность обработки 1 ч & 0,41 \\
\hline
\end{tabular}

Примечание. ИСХ - исходная кора сосны, ВАГ - образец после взрывного автогидролиза, МХА - образец после обработки в барабанной мельнице.
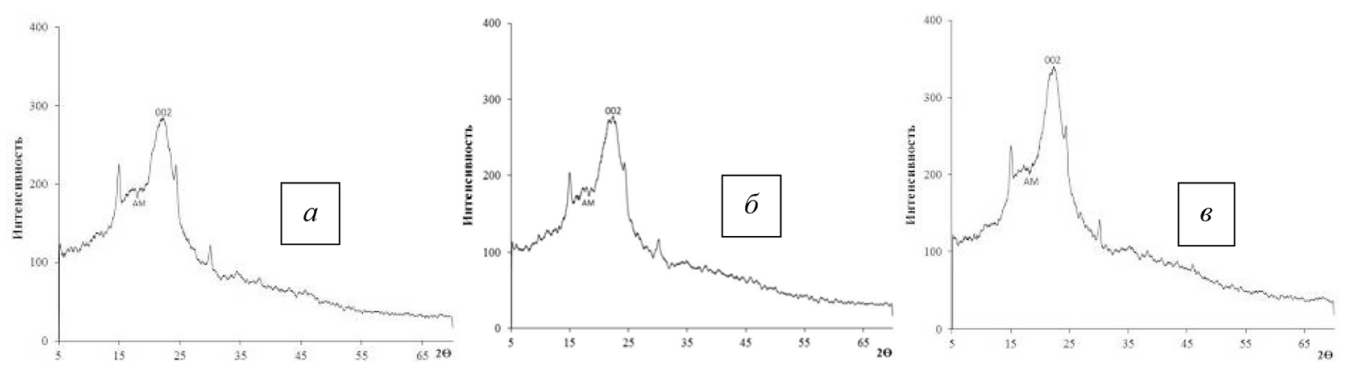

Рис. 3. Дифрактограммы исходной коры сосны (a), образцов после ее активации взрывным автогидролизом (б) и в барабанной мельнице (в). Условия взрывного автогидролиза: температура $120{ }^{\circ} \mathrm{C}$, время 30 с; давление водяного пара 1,0 МПа. Продолжительность активации в барабанной мельнице 1 ч

Fig. 3. The diffractograms of initial pine bark (a), samples after her activation by explosive auto hydrolysis $(\sigma)$ and in ball mill (b). The conditions of explosive auto hydrolysis: temperature $120^{\circ} \mathrm{C}$, time $30 \mathrm{~s}$, water vapour pressure 1,0 MPa. Time of activation in ball mill $1 \mathrm{~h}$

Можно предположить, что к увеличению галло области $21.5^{\circ}$ для образца после активации в барабанной мельнице приводит высвобождение других аморфных составляющих коры (например, лигнина) в результате разрушения тканей коры сосны (рис. 38).

\section{Влияние методов механической активачии коры сосны \\ на выходы и физико-химические экстрактивных веществ \\ Смолистые вещества}

Проведено изучение влияния времени экстракции гексаном в интервале 4-16 ч на выход экстрактивных смолистых веществ из исходной коры ИСХ и образцов после активации взрывным автогидролизом (ВАГ) и механической обработкой в барабанной мельнице (МХА). Полученные результаты приведены на рис. 4. Условия активации соответствуют данным табл. 1.

Как следует из полученных данных, применение выбранных способов активации приводит к увеличению выхода смолистых веществ, а максимальный эффект достигается в случае активации коры сосны взрывным автогидролизом. В зависимости от продолжительности процесса экстракции выход экстрактивных веществ увеличивается в 2-3 раза. Наблюдается линейный рост выходов смолистых веществ из образцов от времени экстрагирования с переходом на плато после 8-9 ч. Появление плато свидетельствует о лимитированной экстракции внутридиффузионными процессами выведения смолистых веществ из объема частиц коры. Заметное 


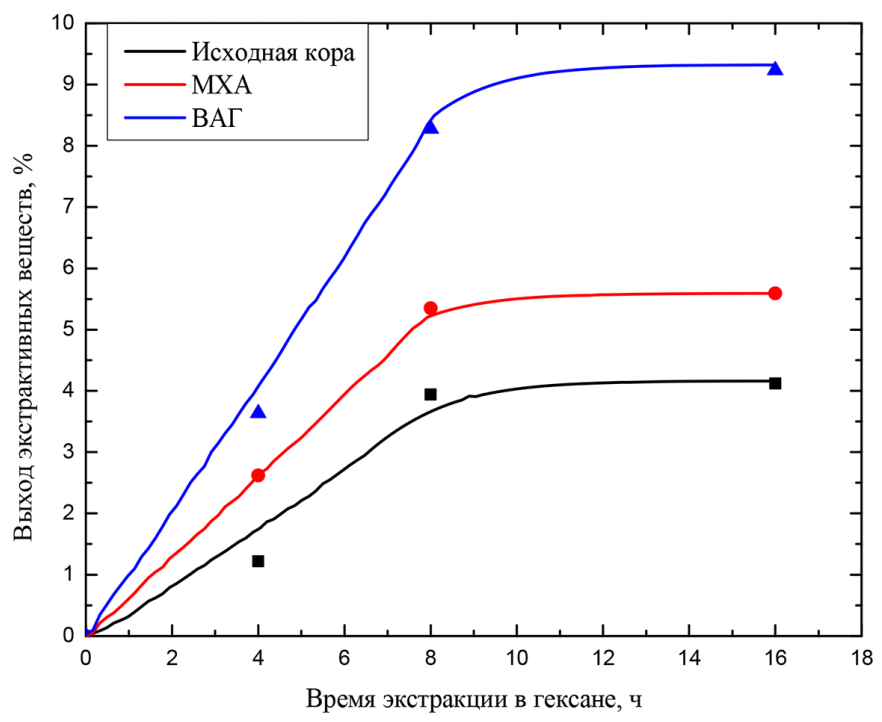

Рис. 4. Зависимости выхода экстрактивных смолистых веществ от времени экстракции в гексане

Fig. 4. Dependence of extractive resinous substances yield versus time extraction in hexane

увеличение выхода смолистых веществ в случае образца ВАГ вызвано уменьшением размера его частиц и развитием пористой текстуры в результате активации. В связи с этим увеличивается площадь поверхности контакта образца с растворителем.

\section{$\beta$-ситостерин}

$\beta$-ситостерин является ценным биологически активным веществом, так как используется в фармацевтической, пищевой и косметической промышленности. В данной работе $\beta$-ситостерин выделяли омылением экстрактивных смолистых веществ, полученных из исходной коры и образцов после ее активации - ВАГ и МХА, спиртовыми растворами $\mathrm{NaOH}$. Ha выход $\beta$-ситостерина влияет как продолжительность экстракции гексаном, так и концентрация спиртощелочного раствора (табл. 2).

Наибольший выход $\beta$-ситостерина наблюдается при использовании образца коры, активированной взрывным автогидролизом, с последующей экстракцией в гексане в течение 8 ч и при использовании омыляющего раствора $\mathrm{NaOH}$ с концентрацией 0,5 н.

Методами ИК-спектроскопии и ${ }^{1} \mathrm{H}$ ЯМР были изучены свойства $\beta$-ситостеринов, выделенных из исходной коры и продуктов ее активации при следующих условиях: экстракция гексаном 16 ч, омыление 0,5 н щелочным раствором.

На рис. 5 приведены ИК-спектры $\beta$-ситостерина, выделенного из исходной коры сосны (кривая 1) и продуктов ее активации ВАГ (кривая 3) и в барабанной мельнице (кривая 2). Сравнение ИК-спектров показывает, что $\beta$-ситостерин из разных образцов характеризуется подобной спектральной картиной. Отличительной особенностью этого вещества, выделенного из продуктов активации ВАГ и в барабанной мельнице, является повышенное содержания ОНгрупп, на что указывает увеличение интенсивности широкой диффузной полосы поглощения (п.п.) при 3425 см$^{-1}$. Наблюдаемый характер этой п.п. обусловлен образованием внутримоле- 
Таблица 2. Выход $\beta$-ситостерина из исходной коры (ИСХ) и образцов после ее активации взрывным автогидролизом (ВАГ) и обработки в барабанной мельнице (МХA)

Table 2. Yield of $\beta$-sitosterin from initial pine bark (ИСХ) and samples after her activation by explosive auto hydrolysis (BAГ) and treatment in ball mill (MXA)

\begin{tabular}{|c|c|c|c|}
\hline Образец & $\begin{array}{c}\text { Время экстракции } \\
\text { в гексане, ч }\end{array}$ & $\begin{array}{c}\text { Концентрация спиртового } \\
\text { раствора едкого натрия, н }\end{array}$ & $\begin{array}{c}\text { Выход } \\
\text { В-ситостерина, \%* }\end{array}$ \\
\hline ИСХ & 4 & 0,5 & 0,009 \\
\hline ИСХ & 4 & 1,0 & 0,008 \\
\hline ИСХ & 8 & 0,5 & 0,034 \\
\hline ИСХ & 8 & 1,0 & 0,011 \\
\hline ИСХ & 16 & 0,5 & 0,025 \\
\hline ИСХ & 16 & 1,0 & 0,018 \\
\hline ВАГ & 4 & 0,5 & 0,023 \\
\hline ВАГ & 4 & 1,0 & 0,006 \\
\hline ВАГ & 8 & 0,5 & 0,078 \\
\hline ВАГ & 8 & 1,0 & 0,038 \\
\hline ВАГ & 16 & 0,5 & 0,018 \\
\hline ВАГ & 16 & 1,0 & 0,036 \\
\hline МХА & 4 & 0,5 & 0,013 \\
\hline МХА & 4 & 1,0 & 0,012 \\
\hline МХА & 8 & 0,5 & 0,036 \\
\hline МХА & 8 & 1,0 & 0,021 \\
\hline МХА & 16 & 0,5 & 0,019 \\
\hline МХА & 16 & 1,0 & 0,004 \\
\hline
\end{tabular}

Примечание. *- от массы навески образца.

кулярных водородных связей [10], что в большей степени выражено для $\beta$-ситостерина после активации коры в барабанной мельнице. В спектрах $\beta$-ситостерина из различных исходных образцов идентифицированы п.п. при 2955, 2917 и $2850 \mathrm{~cm}^{-1}$, обусловленные валентными асимметричными и симметричными колебаниями связи $\mathrm{C}-\mathrm{H}$ в $\mathrm{CH}_{3}$ - и $\mathrm{CH}_{2}$-группах. Полосы поглощения при 1471 и $1378 \mathrm{~cm}^{-1}$ и в области 820-700 $\mathrm{cm}^{-1}$ характеризуют деформационные и внеплоскостные колебания связи $\mathrm{C}-\mathrm{H}$ в $\mathrm{CH}_{3}$ - и $\mathrm{CH}_{2}$-группах $[10,11]$. В составе $\beta$-ситостерина преобладают $\mathrm{CH}_{2}$-группы, что подтверждает высокая интенсивность п.п. при 2917 и $2850 \mathrm{~cm}^{-1}$. $\beta$-ситостерин, выделенный из продуктов активации коры сосны разными способами, характеризуется меньшей интенсивностью п.п. алифатических групп по сравнению с этим веществом из исходной коры. Наименьшая интенсивность вышеперечисленных полос наблюдается в спектре $\beta$-ситостерина, полученного из коры после ее активации в барабанной мельнице (рис. 5).

Отличительной особенностью $\beta$-ситостерина, полученного из образцов после активации коры сосны, является увеличение интенсивности полосы поглощения при $1557 \mathrm{~cm}^{-1}$ за счет колебаний $\mathrm{C}-\mathrm{C}$ - и $\mathrm{C}=\mathrm{C}$-связей циклов в структуре этого соединения [17] по сравнению с $\beta$-ситостерином из исходной коры (рис. 5). Также в ИК-спектрах $\beta$-ситостеринов, полученных из продуктов активации коры сосны, отмечается появление слабых п.п. в области 1440 $1400 \mathrm{~cm}^{-1}$, что свидетельствует о наличии в их структуре групп - $\mathrm{CH}_{2} \mathrm{CO}-$ [11]. 


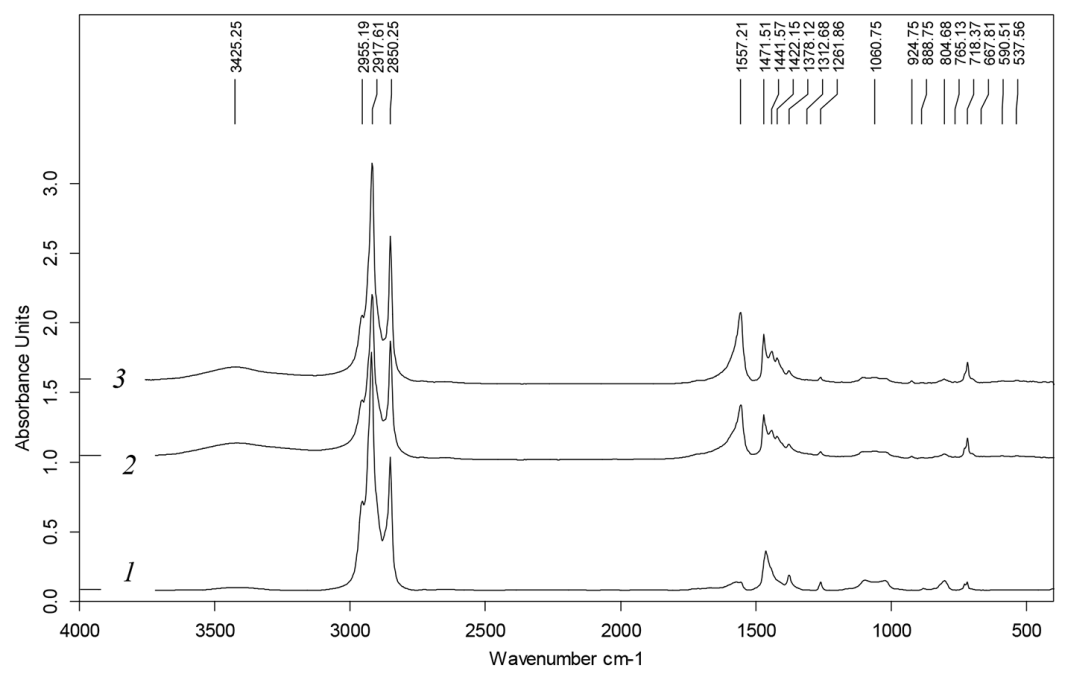

Рис. 5. ИК-спектры $\beta$-ситостерина, выделенного из исходной коры сосны (1) и образцов после ее активации взрывным автогидролизом (2) и в барабанной мельнице (3). Условия взрывного автогидролиза: температура $120^{\circ} \mathrm{C}$, время $30 \mathrm{c}$; давление водяного пара 1,0 МПа. Продолжительность активации в барабанной мельнице 1 ч

Fig. 5. IR-spectrum of $\beta$-sitosterin from initial pine bark (1), samples after her activation by explosive auto hydrolysis (2) and in ball mill (3). The conditions of explosive auto hydrolysis: temperature $120{ }^{\circ} \mathrm{C}$, time $30 \mathrm{~s}$, water vapour pressure 1,0 MPa. Time of activation in ball mill $1 \mathrm{~h}$

В ${ }^{1} \mathrm{H}$ ЯМР-спектрах $\beta$-ситостеринов (рис. 6) основная часть протонов резонирует в интервале 0,70-1,25 м.д. В этой области наблюдается шесть сигналов, соответствующих метильным протонам (Н-18, Н-19, Н-21, Н-26, Н-27, Н-29) [18]. В области 3.56-3.76 м.д. присутствует сигнал протона, связанного с атомом углерода C-3, несущим гидроксильную группу. Сигнал протона двойной связи при С6, характерного для стеролов, находится в области $\sim 5.38$ м.д. [19].

\section{Пектиновые вещества}

Пектиновые вещества древесины извлекают разбавленными растворами кислот (соляной, ортофосфорной и др.) [20]. Для выявления влияния природы кислоты на выход и состав пектиновых веществ сосны образцы после извлечения смолистых веществ в результате экстракции в гексане в течение различного времени делили пополам и обрабатывали $1 \%$-ми растворами соляной и ортофосфорной кислоты соответственно. Данные о выходе пектиновых веществ из исходного образца коры сосны ИСХ и активированных образцов ВАГ и МХА в зависимости от продолжительности предварительного обессмоливания гексаном приведены в табл. 3.

Согласно полученным данным, активация образцов коры сосны привела к значительному повышению степени извлечения пектиновых веществ - примерно в 1,5 раза для образца, активированного взрывным автогидролизом, и в 3 раза в случае образца, механически активированного на барабанной мельнице. Данный факт, очевидно, связан с увеличением доступности пектиновых веществ в результате механического разрушения тканей коры сосны при ее активации. 


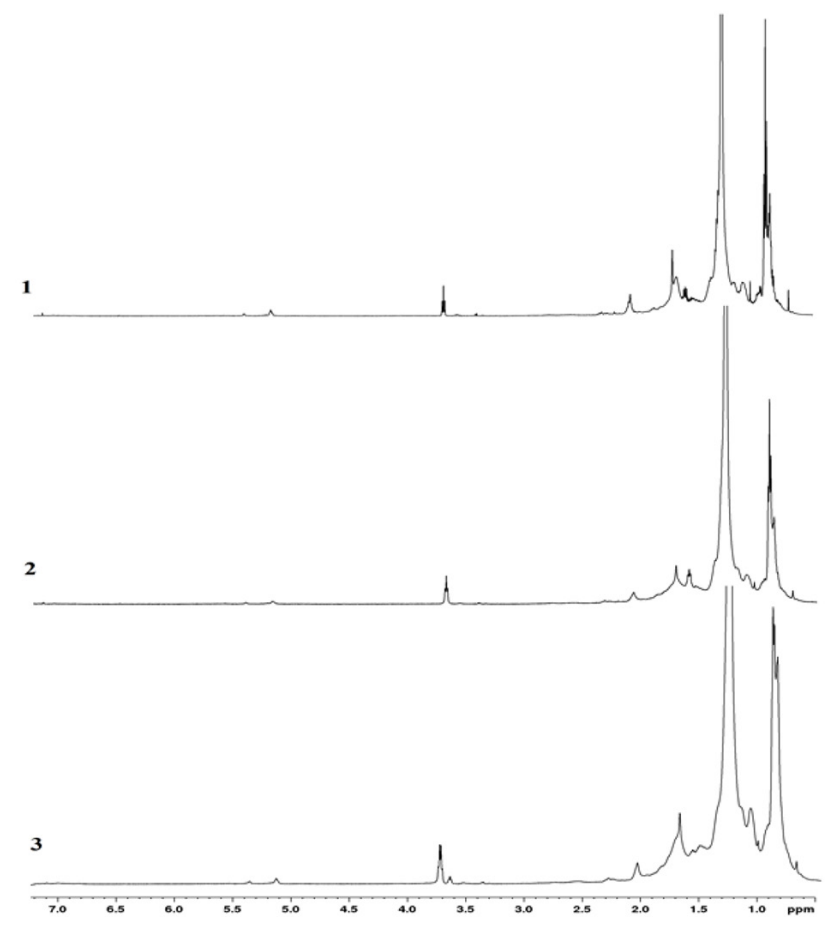

Рис. $6 .{ }^{1}$ Н ЯМР-спектры $\beta$-ситостерина, выделенного из исходной коры сосны (1) и продуктов ее активации $(2,3): 2$ - активация в барабанной мельнице в течение 1 ч; 3 - активация взрывным автогидролизом при следующих условиях: $120^{\circ} \mathrm{C}$, время 30 с, давление водяного пара 1,0 Мпа

Fig. $6 .{ }^{1} \mathrm{H}$ NMR spectrum of $\beta$-sitosterin from initial pine bark (1) and products her activation (2, 3): 2 - activation in ball mill during $1 \mathrm{~h} ; 3$ - activation by explosive auto hydrolysis at following conditions: $120^{\circ} \mathrm{C}$, time $30 \mathrm{~s}$, water vapour pressure $1,0 \mathrm{MPa}$

Для всех трех образцов обессмоленной коры выходы пектиновых веществ оказались несколько выше при их выделении соляной кислотой, что может быть вызвано более высокой мольной концентрацией соляной кислоты (благодаря меньшей молекулярной массе) в $1 \%$-ных растворах. Другой причиной может быть взаимодействие органических соединений в составе коры с хлорид ионами, которые являются более реакционноспособными по сравнению с дигидроксифосфат ионами.

На рис. 7 приведены ИК-спектры пектинов, выделенных из исходной коры сосны (кривая 1) и продуктов ее активации ВАГ (кривая 2), и в барабанной мельнице (кривая 3). Пектиновые вещества были выделены с помощью 1\%-ных растворов соляной кислоты из образцов коры после обессмоливания в течение 16 час.

Сравнение ИК-спектров пектинов из исходной коры и продукта ее активации ВАГ выявило сходство спектральной картины. В их спектрах не наблюдается сдвига характеристических полос поглощения (п.п.). Интенсивность п.п. при $3404 \mathrm{~cm}^{-1}$ (обусловленной колебаниями ОНгрупп в соединениях разной природы), а также п.п. при 2923 и 2852 см$^{-1}$ (колебания связи $\mathrm{C}-\mathrm{H}$ в $\mathrm{CH}_{3}$ и $\mathrm{CH}_{2}$ группах), $1704 \mathrm{~cm}^{-1}$ (колебания $\mathrm{C}=\mathrm{O}$ групп карбоновых кислот, альдегидов и др.), $1614 \mathrm{~cm}^{-1}$ (колебания ароматического кольца, связи $\mathrm{C}=\mathrm{C}$ в алкенах и циклических олефинах), при 1517 см$^{-1}$ (валентные С-С-связи неконденсированных ароматических соединений) заметно 
Таблица 3. Выход пектиновых веществ в результате обработки остатка коры 1\%-ми растворами кислот

Table 3. Yield of pectine substances after treatment of bark residual by $1 \%$ acid solutions

\begin{tabular}{|c|c|c|c|}
\hline Образец & Кислота & $\begin{array}{c}\text { Время экстракции } \\
\text { в гексане, ч }\end{array}$ & $\begin{array}{c}\text { Выход пектиновых } \\
\text { веществ, } \%\end{array}$ \\
\hline ИСХ & $\mathrm{HCl}$ & 4 & 1,69 \\
\hline ИСХ & $\mathrm{HCl}$ & 8 & 2,01 \\
\hline ИСХ & $\mathrm{HCl}$ & 16 & 2,46 \\
\hline ИСХ & $\mathrm{H}_{3} \mathrm{PO}_{4}$ & 4 & 1,51 \\
\hline ИСХ & $\mathrm{H}_{3} \mathrm{PO}_{4}$ & 8 & 1,77 \\
\hline ИСХ & $\mathrm{H}_{3} \mathrm{PO}_{4}$ & 16 & 1,81 \\
\hline ВАГ & $\mathrm{HCl}$ & 4 & 2,07 \\
\hline ВАГ & $\mathrm{HCl}_{2}$ & 8 & 4,58 \\
\hline ВАГ & $\mathrm{HCl}_{3}$ & 16 & 1,51 \\
\hline ВАГ & $\mathrm{H}_{3} \mathrm{PO}_{4}$ & 4 & 3,45 \\
\hline ВАГ & $\mathrm{H}_{3} \mathrm{PO}_{4}$ & 8 & 3,72 \\
\hline ВАГ & $\mathrm{H}_{3} \mathrm{PO}_{4}$ & 16 & 2,53 \\
\hline МХА & $\mathrm{HCl}$ & 4 & 4,26 \\
\hline МХА & $\mathrm{HCl}$ & 8 & 6,71 \\
\hline МХА & $\mathrm{HCl}_{3}$ & 16 & 2,20 \\
\hline МХА & $\mathrm{H}_{3} \mathrm{PO}_{4}$ & 4 & 3,63 \\
\hline МХА & $\mathrm{H}_{3} \mathrm{PO}_{4}$ & 8 & 5,89 \\
\hline МХА & $\mathrm{H}_{3} \mathrm{PO}_{4}$ & 16 & \\
\hline
\end{tabular}

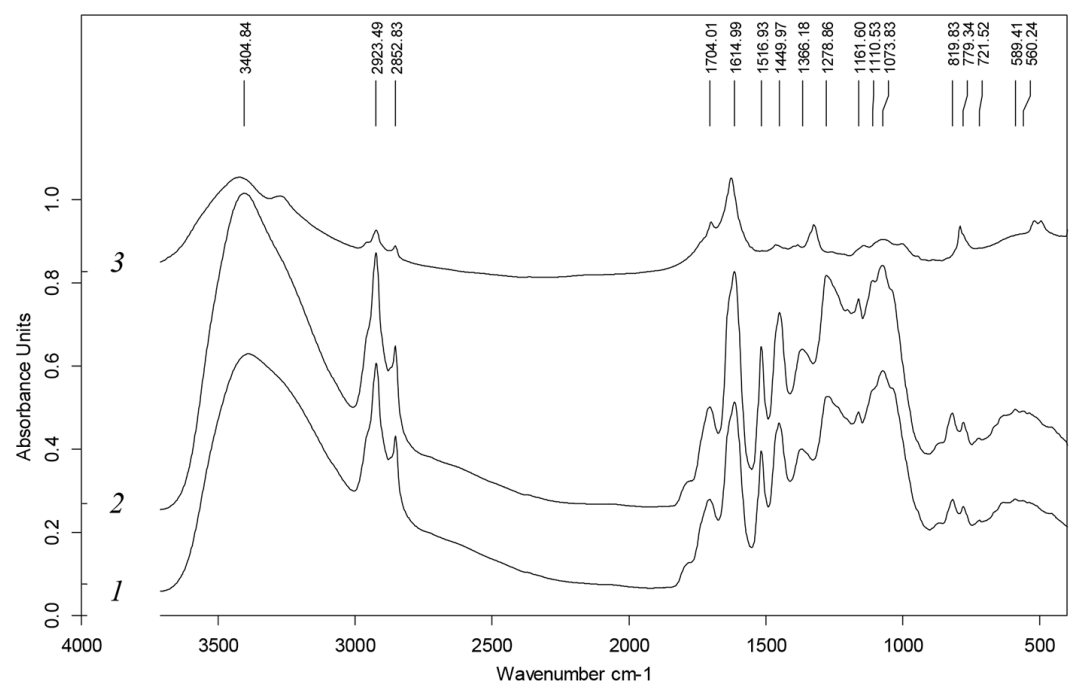

Рис. 7. ИК-спектры пектинов, выделенных из исходной коры сосны (1) и продуктов ее активации (2, 3): 2 активация взрывным автогидролизом при следующих условиях: $120^{\circ} \mathrm{C}$, время 30 с, давление водяного пара 1,0 МПа; 3 - активация в барабанной мельнице в течение 1 ч

Fig. 7. IR spectrum of pectin from initial pine bark (1) and products her activation (2, 3): 2 - activation by explosive auto hydrolysis at following conditions: $120^{\circ} \mathrm{C}$, time $30 \mathrm{~s}$, water vapour pressure $1,0 \mathrm{MPa} ; 3$ - activation in ball mill during $1 \mathrm{~h}$ 
выше в ИК-спектре пектина из продукта активации коры сосны взрывным автогидролизом. Этот образец пектина не только содержит больше первичных и третичных спиртов, в его составе появляются и вторичные спирты, о чем свидетельствует увеличение интенсивности п.п.

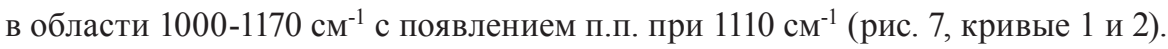

Активация коры сосны в барабанной мельнице приводит к существенному изменению спектральной картины образца, полученного из него по методике выделения пектиновых веществ. Отмечено значительное уменьшение интенсивности п.п. при $3404 \mathrm{~cm}^{-1}$, что согласуется с уменьшением интенсивности поглощения в области 1000-1170 см с $^{-1}$ по сравнению с другими образцами пектина (рис. 7, кривые 3 и 2). Данный факт свидетельствует о незначительном содержании спиртов и эфиров в полученном веществе. Появление полосы при $3274 \mathrm{~cm}^{-1}$ в сочетании с интенсивными полосами при 1626 и $791 \mathrm{~cm}^{-1}$ позволяет предположить наличие в составе данного вещества групп $\mathrm{NH}_{2}$. Вышеперечисленные п.п. отвечают валентным и деформационным колебаниям N-H-связи. Интенсивная п.п. при $1324 \mathrm{~cm}^{-1}$ характерна для валентных колебаний связи C-N $[10,11]$ (рис. 7, кривая 3).

В отличие от пектинов из исходной коры и продукта ее активации ВАГ пектин из коры после измельчения в барабанной мельнице не содержит в своем составе ароматических соединений, поскольку в его спектре не идентифицированы полосы поглощения 1614 и $1516 \mathrm{~cm}^{-1}$. Также отличительной особенностью является и низкое содержание соединений с $\mathrm{C}=\mathrm{O}-$ связью (карбоновых кислот, альдегидов, кетонов и др.), на что указывает существенно меньшая интенсивность п.п. при 1704 см$^{-1}$ (рис. 7, кривая 3). Сравнение ИК-спектров показало нецелесообразность применения активации коры сосны в барабанной мельнице для последующего выделения пектина за счет значительного разрушения структуры этого полимера на стадии механического измельчения.

На рис. 8 приведены ЯМР-спектры пектиновых веществ, выделенных с помощью 1\%-ных растворов соляной и ортофосфорной кислот из образца коры, активированной ВАГ, после обессмоливание в течение 16 ч.

Исходя из общего вида спектров, можно сделать вывод о наличии различных функциональных групп: метильных (1.0-1.4 м.д.); ацетильных ( 2.0 м.д.); метоксильных (3.6-3.9 м.д.) и карбоксильных (5.0-5.2 м.д.). Наблюдаются также пики протонов, принадлежащих атомам углерода пиранозных циклов звеньев галактуроновой кислоты в областях 4.8-5.1 м.д. (Н-1), 3.6-4.2 м.д. (Н-2 и Н-3), 4.1-4.5 м.д. (Н-4), 4.4-5.2 м.д. (Н-5) и рамнопиранозы при 5.0-5.2 (Н1) и 3.2-3.4 (Н-4) [21, 22]. Следует отметить, что в ${ }^{1} \mathrm{H}$ ЯМР-спектрах также имеются сигналы, относящиеся к атомам водорода других полисахаридных остатков, входящих в состав макромолекул пектиновых веществ. Однако из-за значительной ширины и наложения части сигналов произвести каких-либо информативных отнесений без привлечения других методик ЯМРспектроскопии не представляется возможным.

\section{Заключение}

Проведены исследования физико-химических свойств продуктов активации коры сосны методом взрывного автогидролиза и механического измельчения в барабанной мельнице. Полученные данные показали, что эти воздействия приводят к заметному уменьшению среднего размера частиц коры и разрушению структуры полимеров, входящих в ее состав.

$$
-443-
$$




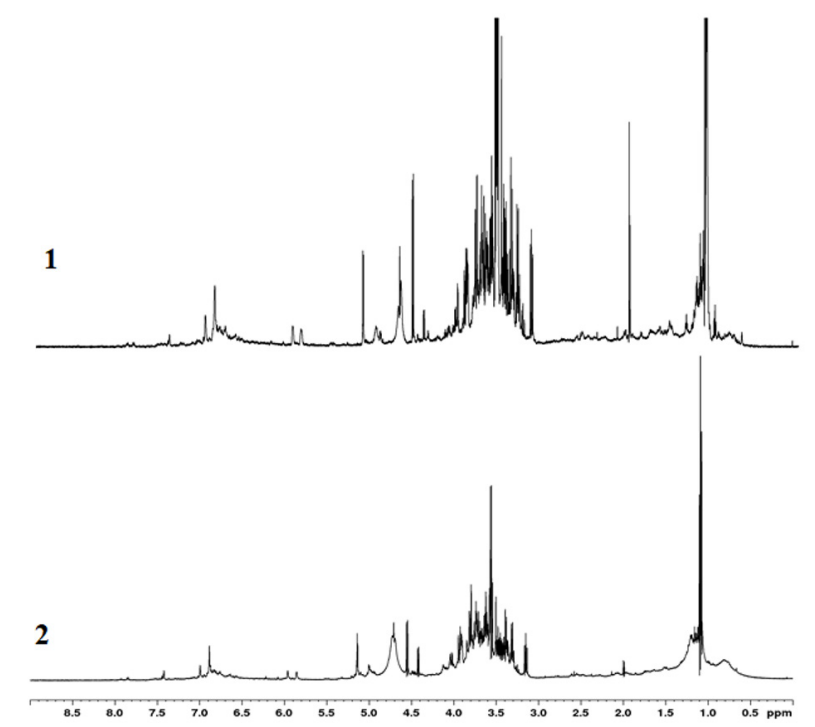

Рис. $8 .{ }^{1}$ Н ЯМР-спектры пектинов, выделенных из коры сосны, активированной взрывным автогидролизом при $120{ }^{\circ} \mathrm{C}$, время $30 \mathrm{c}$, давление водяного пара $1,0 \mathrm{MПа:} 1$ - с использованием $1 \%$ раствора соляной кислоты; 2 - с использованием 1\%-ного раствора ортофосфорной кислоты

Fig. $8 .{ }^{1} \mathrm{H}$ NMR spectrum of pectins from pine bark activated by explosive auto hydrolysis at $120{ }^{\circ} \mathrm{C}$, time $30 \mathrm{~s}$, water vapour pressure 1,0 MPa: 1 - with the use of $1 \%$ hydrochloric acid solution; 2 - with the use of $1 \%$ orthophosphoric acid solution

Изучено влияние этих способов активации коры сосны на выходы и физико-химические свойства экстрактивных веществ (смолистых и пектиновых веществ, $\beta$-ситостерина). Подукты экстракции изучены методами ИК- и ${ }^{1} \mathrm{H}$ ЯМР-спектроскопии. Показано, что активация коры сосны позволяет существенно увеличить выходы всех целевых продуктов. Сравнение примененных способов активации показало большую эффективность взрывного автогидролиза. По результатам проведенных исследований определены лучшие условия для выделения целевых экстрактивных веществ. Для смолистых веществ и $\beta$-ситостерина - активация взрывным автогидролизом, концентрация щелочи 0.5 н. Для пектиновых веществ - активация взрывным автогидролизом, использование соляной кислоты.

\section{Благодарности / Acknowledgements}

Работа выполнена при финансовой поддержке Российского фонда фундаментальных исследований и Красноярского краевого фонда поддержки научной и научно-технической деятельности (проект № 19-43-240011). Авторы выражают признательность м.н.с. И.В. Корольковой за регистрацию ИК-спектров, н.с. Г.Н. Бондаренко за анализ образцов методом рентгенофазового анализа. В работе использовано оборудование Красноярского регионального центра коллективного пользования ФИЦ КНЦ СО РАН.

This work was financially supported by the Russian Foundation for Basic Research and the Krasnoyarsk Regional Foundation for the Support of Scientific and Scientific and Technical Activities (project No. 19-43-240011). The authors are grateful to junior researcher I.V. Korolkova for registration of IR spectra, researcher G.N. Bondarenko for the analysis of samples by X-ray phase analysis. The 
equipment of the Krasnoyarsk Regional Center of Research Equipment of Federal Research Center «Krasnoyarsk Science Center SB RAS» was used in the work.

\section{Список литературы / References}

1. Мельман И.В. Лесопромышленный комплекс Красноярского края и проблема повышения его конкурентоспособности. Региональная экономика: теория и практика. 2008. Т. 26, C. 29-35. [Melman I.V. Krasnoyarsk region timber industry complex and the problem of increasing its competitiveness. Regional economy: theory and practice 2008. Vol. 26, P. 29-35. (in Russ.)]

2. http://newslab.ru/news/818260.

3. Соболев С.В., Трофимук В.Н. Проблемы комплексности использования сырья на деревобрабатывающих предприятиях Красноярского края. Успехи современного естествознания. 2004. C. 168-171. [Sobolev S.V., Trofimuk V.N. Krasnoyarsk Territory raw materials use complexity problems at wood-processing enterprises. Success of modern natural science 2004. P. 168-171 (in Russ.)]

4. Веприкова Е.В., Терещенко Е.А., Щипко М.Л., Кузнецов Б.Н. Сорбенты для ликвидации нефтяных загрязнений, полученные автогидролизом древесных отходов. Экология и промылиленность России. 2011. № 6, C. 16-20. [Veprikova E.V., Tereshchenko E.A., Shchipko M.L., Kuznetsov B.N. Oil pollution sorbents for the elimination obtained by autohydrolysis of wood waste. Ecology and Industry of Russia. 2011. No. 6, P. 16-20 (in Russ.)]

5. Гравитис Я.А. Теоретические и прикладные аспекты метода взрывного автогидролиза растительной биомассы. Химия древесины. 1987. № 5, С. 3 - 21. [Gravitis Ya.A. Plant biomass explosive autohydrolysis, theoretical and applied aspects method. Wood Chemistry. 1987. No. 5, P. 3 21 (in Russ.)]

6. Yeh A.I., Huang Y.C., Chen S.H. Effect of particle size on the rate of enzymatic hydrolysis of cellulose. Carbohydrate polymers. 2010. Vol. 79. No. 1. P. 192-199.

7. Рязанова Т.В., Чупрова Н.А., Ким Н.Ю. Об интенсификации процесса экстракции коры лиственницы сибирской в дезинтеграторе. Химия растительного сырья. 2000. № 1, С. 95-100. [Ryazanova T.V., Chuprova N.A., Kim N.Yu. Siberian larch bark process extraction intensification in a disintegrator. Chemistry of plant raw materials. 2000. No. 1, P. 95-100 (in Russ.)]

8. Разумовский С.Д., Подмастерьев В.В., Зеленецкий А.Н. Механохимические методы активации процессов предобработки биомассы. Катализ в промышленности. 2010. № 5, С. 5357. [Razumovsky S.D., Podmaster'ev V.V., Zelenetsky A.N. Mechanochemical methods for activating biomass pre-treatment processes. Catalysis in industry. 2010. No. 5. P. $53-57$ (in Russ.)]

9. Пестунов А.В., Кузьмин А.О., Яценко Д.А., Правдина М.Х., Таран О.П. Механическая активация чистой и содержащейся в древесных опилках целлюлозы в мельницах различного типа. Журнал Сиб. фед. ун-та. 2015. Т. 8. № 3, С. 386-400. [Pestunov A.V., Kuzmin A.O., Yatsenko D.A., Pravdina M.Kh., Taran O.P. Mechanical activation of pure cellulose and cellulose contained in sawdust in mills of various types. Journal of Siberian Federal University. 2015. Vol. 8. No. 3. P. 386-400 (in Russ.)]

10. Sokrates G. Infrared and Raman characteristic group frequencies: Tables and charts. West Sussex: Wiley Sons, 2001. 347 p.

11. Преч Э., Бюльманн Ф., Аффольтер К. Определение строения органических соединений. М.: Мир, БИНОМ лаборатория знаний, 2006. [Pretsch E., Bühlmann F., Affolter К. 
Organic compounds structure determination. M.: Mir, BINOM laboratory of knowledge, 2006 (in Russ.)]

12. Барышников С.В., Шарыпов В.И., Жижаев А.М., Береговцова Н.Г., Кузнецов Б.Н. Изменение структурной упорядоченности древесины осины в процессе ее механохимической активации и гидролиза. Журнал Сиб. фед. ун-та. Химия. 2010. Т. 3. № 2, С. 120-127. [Baryshnikov S.V., Sharypov V.I., Zhizhaev A.M., Beregovtsova N.G., Kuznetsov B.N. Aspen wood changes the structural ordering in the process of its mechanochemical activation and hydrolysis. Journal of the Siberian Federal University. Chemistry. 2010. Vol. 3. No. 2, P. 120-127 (in Russ.)]

13. Беушева А.А., Скурыдин Ю.Г., Скурыдина Е.М., Беушева О.С., Коньшин В.В. Рентгеноструктурный анализ гидролизованной древесины лиственницы. Ползуновский вестник. 2016. № 2, C. 192-197. [Beusheva A.A., Skurydin Yu.G., Skurydina E.M., Beusheva O.S., Konshin V.V. Hydrolyzed larch wood X-ray structural analysis. Polzunovskii Vestnik. 2016. No. 2, P. 192-197 (in Russ.)]

14. Huang Z.Q., Xie X.L., Chen Y. et al. Ball-milling treatment effect on physicochemical properties and features for cassava and maize starches. Comptes Rendus Chimie. 2008. Vol. 11. No. 1-2. P. 73-79.

15. Gromov N.V., Taran O.P., Parmon V.N. CHAPTER 3 Catalysts for Depolymerization of Biomass. Sustainable Catalysis for Biorefineries, eds. Frusteri, F., Aranda, D., Bonura, G. The Royal Society of Chemistry, 2018. P .65-97.

16. Gromov N.V., Taran O.P., Sorokina K.N., Mishchenko T.I., Uthandi S., Parmon V N. New methods for the one-pot processing of polysaccharide components (cellulose and hemicelluloses) of lignocellulose biomass into valuable products. Part 1: Methods for biomass activation. Catalysis in Industry. 2016. Vol. 8. No. 2, P. 176-186.

17. Круглякова А.А., Раменская Г.В. Бета-ситостерин: свойства, подходы к количественному определению. Вестник Национального медико-хирургического иентра им. Н.И. Пирогова. 2016. T. 11, № 4, С. 35-38. [Kruglyakova A.A., Ramenskaya G.V. Beta-sitosterol: properties, approaches to quantitative determination. Bulletin of the National Medical and Surgical Center named after N.I. Pirogov. 2016. Vol. 11, No. 4, P. 35-38 (in Russ.)]

18. Nyigo V.A., Peter X., Mabiki F., Malebo H.M., Mdegela R.H., Fouche G. Isolation and identification of euphol and $\beta$-sitosterol from the dichloromethane extracts of Synadenium glaucescens. The Journal of Phytopharmacology. 2016. Vol. 5(3), P. 100-104.

19. Prabakaran M., Kim S-H., Sasireka A., Hemapriya V., Chung I.-M. $\beta$-Sitosterol isolated from rice hulls as an efficient corrosion inhibitor for mild steel in acidic environments. New J. Chem., 2017. Vol. 41, P. 3900-3907.

20. Кузнецов Б.Н., Левданский В.А., Кузнецова С.А. Химические продукты из древесной коры. Красноярск: Сиб. федер. ун-т, 2012. 260 с. [Kuznetsov B.N., Levdanskiy V.A., Kuznetsova S.A. Chemical products from wood bark: monograph. Krasnoyarsk: Siberian Federal University, 2012. 260 p. (in Russ.)].

21. Marcon M.V., Carneiro P.I.B., Wosiacki G., Beleski-Carneiro E. Pectins from Apple Pomace characterization by ${ }^{13} \mathrm{C}$ and ${ }^{1} \mathrm{H}$ NMR spectroscopy. Ann. Magn. Reson. 2005. Vol. 4(3), P. 56-63.

Zhi Z., Chen J., Li S., Wang W., Huang R., Liu D., Ding T., Linhardt R.J., Chen S., Ye X. Fast preparation of RG-I enriched ultra-low molecular weight pectin by an ultrasound accelerated Fenton process. Sci. Rep. 2017. Vol. 7(1), P. 541. 